\title{
The Nazi Regime-Ideology, Ascendancy, and Consensus
}

This chapter delineates the Nazi regime's construction and promulgation of an ideology that saw many ordinary and mildly antisemitic Germans condone or feel indifferent about the infliction of harm on Jews and other "sub-humans." Much like the Obedience study's persuasion phase (see Volume 1), I argue that, mostly at the hands of the Nazi regime, Germany's "informational and social field" underwent a "calculated restructuring," the consequence of which saw the harming of others morally inverted into a social good.

\section{The Origins of Nazi Ideology and Their Rise to Power}

In the sixteenth century, the German Protestant reformer Martin Luther reflected on how Christians in Europe should deal with the small Jewish communities living in their midst. After vilifying the "rejected race of Jews" as liars and blasphemes, he recommended a "merciful severity": burn down their synagogues, destroy their homes, appropriate their valuables, and stamp out their proselytizing - so "we may all be free of this insufferable devilish burden - the Jews." 2 To this point, terrifying violence of the sort Luther recommended had not been a major threat to the survival of European Jews. Attacks on Jews (pogroms) were more typically fueled by emotion and were, by nature, too disorganized to systematically wipe out entire and multiple Jewish communities.

Indeed, from the seventeenth century onward, the Enlightenmentthe spread of humanist rationalism and secularism across Western

(C) The Author(s) 2019 https://doi.org/10.1007/978-3-319-97999-1_2 
Europe-coincided with a sharp decline in pogrom violence. ${ }^{3}$ Beginning in the late eighteenth century, and especially throughout the nineteenth century, the most progressive European nations including Germany, Holland, Denmark, France, and Great Britain all granted their Jewish communities equal rights. Many Jewish communities thrived socially, culturally, and economically. But many Christians also continued to harbor animosity toward their Jewish neighbors. The German composer Richard Wagner said in 1881:

I hold the Jewish race to be the born enemy of pure humanity and everything noble in it. It is certain that it is running us Germans into the ground, and I am perhaps the last German who knows how to hold himself upright in the face of Judaism, which already rules everything. ${ }^{4}$

In 1899, Englishman Stewart Chamberlain expressed similar views in his best seller The Foundations of the 19th Century, which had run into its tenth edition by the early twentieth century. ${ }^{5}$

A few decades earlier in 1859, Charles Darwin published his seminal work On the Origin of Species. Darwin's book had a profound effect on his cousin Francis Galton, who applied the basic tenets of Darwin's new theory to human beings. Galton's efforts led to a new field of academic inquiry-eugenics, defined by the twentieth-century Harvard biologist Charles B. Davenport as, "the science of the improvement of the human race by better breeding." into two main schools: positive and negative. Positive eugenics calls for adding so-called desirable human characteristics to what then becomes a stronger gene pool. For example, a government might allow certain immigrants to enter their country because they believe them to have certain desirable genetic characteristics. Negative eugenics, however, aims to remove "undesirable" genetic characteristics from the gene pool, for example by sterilizing citizens with apparent genetic predispositions toward, say, alcoholism or drug addiction. Influential supporters of negative eugenics included prominent German scholars like Ernst Haeckel who in the early twentieth century argued in favor of the ancient Spartan strategy of eliminating any weak or sickly babies from their communities in order to strengthen the wider gene pool. ${ }^{7}$ Around the same time, Karl Pearson, an early twentieth-century English mathematician, argued that nations should be "kept up to a high pitch of external efficiency by contest, chiefly by way of war with inferior races, and with equal races 
by the struggle for trade routes and the sources of raw materials and

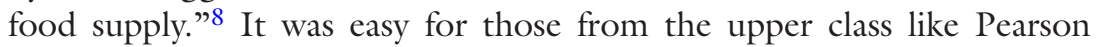
to espouse such destructive beliefs because when nations went to waras they did during World War One (1914-1918) - their lives were rarely put in harm's way. It was the proverbial working-class "cannon fodder," structurally excluded from the distant safety of the officer ranks, who almost exclusively paid the price for the decisions by elites to go to war and expend, as it turned out, millions of genetically healthy lives in the trenches. This class bias extended to Germany's home front. For example, during the British Naval blockade (1915-1919), more than 400,000 mostly working-class German civilians starved to death. ${ }^{9}$ Such class iniquities before and leading up to Germany's eventual World War One defeat ensured the Reich's brief experiment with democratic governance - the ill-fated Weimar Republic (1919-1932)—was marred by political instability frequently fueled by lower-class demands for a fairer and more egalitarian German society. ${ }^{10}$

Soon after the Weimar Republic came to power, in 1920 the publication of Binding and Hoche's The Destruction of Life Unworthy of Life saw the popularity of negative eugenics grow. ${ }^{11}$ This book claimed that during World War One, as the strongest Germans were dying in droves on the frontlines, the lives of the apparently weakest genetic stock (those ineligible for military service) were safely preserved back in Germany. This preservation of the inferior over the superior was, they argued, weakening Germany's wider gene pool. A year later, Baur, Fischer, and Lenz published what became the leading German text on negative eugenics, Outline of Human Genetics and Racial Hygiene. ${ }^{12}$ Those convinced by this increasingly popular literature started appealing to the country's political elite. For example, in 1923 the director of a Saxony health institute tried (unsuccessfully) to convince a minister in the Weimar government that, "what we radical hygienists promote is not at all new or unheard of. In a cultured nation of the first order, in the United States of America, that which we strive toward was introduced and tested long ago." 13 Indeed, Germany trailed behind the USA, the world's leader in negative eugenics, which, first in Indiana in 1907, and then in half of all the states by the 1930s, ${ }^{14}$ became "the first country to pass laws calling for compulsory sterilization in the name of racial purification" [italics original]. ${ }^{15}$ Having said this, the sterilization of Americans was, relative to the country's population, a seldom applied policy. ${ }^{16}$ Elsewhere, Switzerland and several Scandinavian countries introduced 
laws in the 1920s aimed at the sterilization of certain institutionalized peoples. ${ }^{17}$ Although across the early twentieth century the German medical profession tended to favor the far less radical field of positive eugenics, the tide was starting to change. For example, in 1932, just before the Nazi Party took power, the Weimar government drafted a voluntary sterilization law aimed at those with disabilities. ${ }^{18}$ The law introduced on I January 1934 prompted Joseph S. DeJarnette, the superintendent of a hospital in Virginia, to claim in frustration, "The Germans are beating us at our own game." 19

For the wider German public, awareness of negative eugenics came through sources more mainstream than medical treatises, including Adolf Hitler's 1925 autobiography, Mein Kampf (My Battle or My Struggle). ${ }^{20}$ Hitler, a decorated World War One veteran and disgruntled leader of the right-wing Nazi Party, wrote this book while serving a prison sentence for a failed attempt in 1923 to overthrow the Weimar government. As early as 1920, the Nazi Party capitalized on the widespread postwar class tensions by advocating for "the uniting of all Germans within the one greater Germany..." They added, however, one caveat: Only "persons of German blood" could be nationals. ${ }^{21}$ Hitler was basically advocating in favor of a race-based welfare state where greater class equality would be offered to all genetically healthy true-blooded Germans. ${ }^{22}$ All outsiders, however, were to be excluded from receiving any Nazi welfareparticularly Germany's Jews, a group Hitler frequently dehumanized using terms like "bacilli," "spongers," "parasites," "poisonous mushrooms," and "rats..." 23 As Götz Aly notes, here "Nazi ideology conceived of racial conflict as an antidote to class conflict"- a predictably popular political strategy because it propagated "two age-old dreams of the German people: national and class unity." 24

Then again, not everybody across early twentieth-century Germany felt as Hitler and the Nazi Party did toward the Jews. For example, Jewish political candidates during Germany's 1912 election won one-seventh of the seats in the Reichstag. This was an impressive feat since Germany's Jews made up only $1 \%$ of the national population. Success at the polls saw some in conservative political parties bitterly dub this election the "Jewish elections." 25 Putting the pockets of dissent aside, this electoral success clearly indicates that many non-Jewish Germans must have felt quite positively toward their Jewish political representatives.

Although some believe the origins of Hitler's intense antisemitism can be traced back to his more formative years, ${ }^{26}$ others suspect it was 
largely stimulated by his post-1919 belief that Germany's Jews were to blame for the Reich's loss of World War One, along with the great loss of German lives and land this defeat entailed. ${ }^{27}$ Hitler believed Germany had not been defeated militarily (which in fact it had), ${ }^{28}$ but instead lost the war and, as part of the Treaty of Versailles, almost oneeighth of its territory because Jewish leaders had treasonously stabbed their own nation in the back by submitting to the Allies. Germany's Jews did so, according to Hitler, with the sole intention of advancing their own social and economic position, pursuits that only highlighted their moral inferiority. Much like Wagner, Hitler also believed there existed a cunning group of international Jewish financiers whose machinations involved aspirations of worldwide economic domination. His developing ideology amalgamated ideas from Baur, Fischer, and Lenz on negative eugenics with his own on German nationalism. ${ }^{29}$ This theoretical synthesis cemented the structural foundations of what would become Nazism, which according to Müller-Hill:
claimed that there is a biological basis for the diversity of Mankind. What makes a Jew a Jew, a Gypsy a Gypsy, an asocial individual asocial, and the mentally abnormal mentally abnormal is in their blood, that is to say in their genes. All...are inferior. There can be no question of equal rights for inferior and superior individuals, so, as it is possible that inferior individuals breed more quickly than the superior, the inferior must be isolated, steri- lized, rejected, and removed, a euphemism for killed. If we do not do this, we make ourselves responsible for the ruin of our culture. ${ }^{30}$

Clearly, Nazi ideology was not singularly concerned with Jewssomething would also have to be done about other threatening and "inferior" groups. Having said that, there is no doubt Hitler had an incomparable and singular hatred of Jews, a group he believed posed a great moral and genetic threat to the Western world. In fact, not long after the formation of the Nazi Party, Hitler threatened:

As soon as I have power [he said in 1922] I shall have gallows erected, for example in Munich in the Marienplatz. Jews will be hanged one after another and they will stay hanging until they stink ... then the next group will follow ... until the last Jew in Munich is exterminated. Exactly the same procedure will be followed in other cities until Germany is cleansed of the last Jew. ${ }^{31}$ 
Whether rich or poor, powerful or powerless, inferior or cunning, capitalist or communist, German or otherwise, if they were Jews then they were to blame. As Browning put it, for Hitler "the 'Jewish question' was the key to all other problems and hence the ultimate problem." ${ }^{32}$ Much of the disdain traced back to plan old jealousy. That is, because within Jewish culture there has long been a deeply rooted dedication to studious habits and the pursuit of higher learning, in a modern meritocracy like Germany where opportunity (relatively speaking) abound, German Jews punched well above their weight. In terms of conventional measures of success, across the first third of the twentieth century, German Jews were disproportionately represented in the legal and medical professions. But perhaps most impressively, although German Jews only made up $1 \%$ of the population, between 1905 and 1937 nearly $37 \%$ of all German Nobel Laureates had Jewish ancestry. ${ }^{33}$ Particularly among the many disaffected non-Jewish Germans who, like Hitler, failed to measure up, the scapegoat of blaming a visibly successful minority for all their own personal failures proved all too tempting. Importantly, Hitler's views conflicted with Christianity's traditional solution to the apparent threat of Judaism: religious conversion and assimilation. As far as Hitler was concerned, converting Jews into Christians would not eliminate the risk they posed to the "superior" Germanic bloodline. Assimilation, for Hitler, was tantamount to collective Germanic suicide.

On the other side of Nazi ideology's application of negative eugenics lay Lebensraum, the imperial quest to obtain more land or "living space..." 34 This notion drew on the tenets of positive eugenics. According to Hitler, if the "Germanic race" were indeed to thrive, then the ten million or so "high grade" 35 ethnic Germans living abroad in Eastern Europe needed to be repatriated. Together, Germany and Germans from near and far would become stronger. To accommodate this influx, however, Germany (apparently) required more land. It was this need for more living space that the Nazi regime used to bolster the necessity of going to war. ${ }^{36}$ As far as Hitler was concerned, this land would best come from beyond the Reich's eastern national borderPoland and the Soviet interior. Annexing other nations' sovereign lands and unavoidably decimating large numbers of the native populations of those countries hardly bothered Hitler who saw Lebensraum as just another chapter in Western European colonialism. ${ }^{37}$ Western nations like France, Holland, Britain, Italy, and indeed nineteenth-century Germany had all colonized other lands-why shouldn't modern Germany do so 
too. Hitler himself referenced Britain's empire when he said, "The Russian space is our India." 38 With a tip of his hat to formal rationality, why bother inefficiently traveling halfway across the world when a colonial empire so conveniently lay next door? While colonization awaited victory in war, removal of Germany's Jews offered a more immediate solution to freeing up living space in Germany itself. If the Nazis ever came to power, removing Germany's Jews would be a priority.

From 1924 onward, the popularity of the Nazi Party increased, particularly among young, unemployed working-class men who, for reasons just mentioned, reveled in Hitler's uncouth tirades against the Jews. Appealing only to this demographic, however, was no road to political power. The Nazi Party won only 12 of 608 electoral seats in the 1928 election. ${ }^{39}$ For subsequent elections, most obviously from 1930 onward, ${ }^{40}$ the Party adopted a new strategy. It tailored its nationalistic message to appeal to all Germans, only emphasizing their hatred of the Jews in the presence of antisemitic audiences. Increasingly, a new, subtle, seemingly less radical, and more presidential Hitler emerged. ${ }^{41}$ As a fearless crusader in pursuit of righting widely shared nationalistic wrongslike the unpopular Treaty of Versailles-a new Hitler spoke largely of "honor, struggle, glory, and morality." 42 The Nazi Party's new and more appealing nationalistic campaign strategy also focused on "[e]motionally powerful but programmatically vague slogans such as 'Freedom and Bread!' and 'Order at Home and Expansion Abroad..."'43 During his now broadly alluring feel-good speeches, Hitler reinforced this political ambiguity, advocating in favor of "Volk and fatherland ... the eternal foundation of our morality and our faith" along with "the preservation of our Volk." 44 While other politicians talked of tax reform and economic policy, Hitler's affective, yet pragmatically empty, orations saw his popularity among many German patriots soar. Much has been made of Hitler's spellbinding hypnotic charisma. Although he was undoubtedly a gifted public speaker, the success behind his rising appeal was less mysterious. In terms of his ability to bring many within the crowd to his side, like the consummate salesperson, Hitler:

would begin by acquainting himself with his audience and studying their reactions to several topics. When he had identified their desires, he would explain confidently why only his Nazi movement could fulfill them. Listeners would say to themselves, 'Of course, that's just what I have always believed. ${ }^{45}$ 
The Nazi Party's strategic move away from mere Jew-baiting and toward their more upbeat formula of populist patriotism may have been timely because by the late 1920s one indicator at least suggests that for the first time since the defeat of 1918, German nationalism was undergoing a revival. More specifically, by the late 1920s German war memorials had changed from typically conveying grief over the enormous loss of (working-class) lives to instead emphasizing Germany's World War One battle victories, glorifying individual acts of bravery, and promoting awareness of wars that advanced German unification. ${ }^{46}$ Those critical of the jingoistic folly of this shift were, as they usually are, criticized and then dismissed as unpatriotic. ${ }^{47}$ Perhaps the Weimar Republic supported this stylistic change in war commemorations because, as the start of World War One showed, when class relations were tense nothing united all Germans quite like militant Prussian nationalism. ${ }^{48}$ Obviously, the Nazi Party also sensed this cultural shift, but unlike other political parties, none were led by a fiercely passionate war veteran with oratorical skills so perfectly suited to capitalizing on a rising wave of nationalistic fervor. Then, in the wake of the 1929 stock market crash, Hitler moved on to politically exploiting the miseries of the Great Depression: Weimar democracy, he argued, was clearly failing poor Germans; however, his Nazi welfare state promised to provide for all [healthy Aryan] citizens. During the 1930 election, rising nationalism and the Great Depression saw the Nazis experience a phenomenal ninefold improvement at the ballot box. However, even this success only translated into 107 parliamentary seats, leaving the Nazis a minority political party. ${ }^{49}$

As the Nazi Party's star rose, Hitler asked fellow World War One veteran Ernst Röhm in 1930 to increase the dwindling ranks of the Nazi SA (the Nazi Party's paramilitary arm-the so-called Stormtroopers). The SA formed in 1921 and consisted mostly of disaffected working-class war veterans. Hitler promised that for his services, if the Nazi regime came to power, Röhm would be granted the authority to pursue a revolution against wealthy Jews. This deal made sense to Hitler because if the Nazis ever governed Germany, he intended to fund his Aryan welfare state by exploiting the Jews and other "subhumans..." 50

Meanwhile, the Nazis continued to pursue their winning political strategy of appealing to the widest possible audience. ${ }^{51}$ Finally, the election of 1932 bore real fruit: The Nazi Party won 230 parliamentary seats or $37.3 \%$ of the national vote. ${ }^{52}$ The political might that came with obtaining just over a third of the national vote was accentuated by 
the emergence of cracks within the left-wing parties, whose otherwise greater collective power was diminished due to internal squabbling. ${ }^{53}$ The Nazi Party, therefore, emerged from the election as the single largest party in the Reichstag.

President Paul von Hindenburg, however, refused to support Hitler's bid for the chancellor's seat, but the Reichstag rejected von Hindenburg's preferred candidate, Franz von Papen, the leader of the conservative Catholic Center Party. New elections were set for the end of the year, the result of which saw support for the Nazi Party slip to around 33\%. Paul von Hindenburg again overlooked Hitler as chancellor, this time favoring Kurt von Schleicher, but he too proved unpopular with the Reichstag. After some political wrangling, von Papen suggested a compromise: make Hitler chancellor but only on the condition that the Nazi Party obtain just two of the remaining eleven cabinet seats. Furthermore, Röhm was to be estranged from the Nazi Party, and Hitler would cede to the dictates of those who would become his new friendsconservatives in big business. Von Papen added that should Hitler fail to abide by these conditions, von Hindenburg could instruct the Wehrmacht (the Germany army) to remove the entire Nazi Party. ${ }^{54}$ Von Papen's underlying intention, it transpires, was to provide Hitler with the image of political power while his fellow members of the Catholic Center Party dominated the cabinet, structurally retaining all power for themselves (and their arch-conservative party colleagues). With the Nazi Party's recent slip in the polls, a more desperate Hitler accepted von Papen's conditions, thus obtaining the coveted chancellor's seat. This is not, of course, how the sanctimonious Hitler publicly presented his accent-morally transcending politicians' usual desperation for power, his acceptance of the chancellorship had apparently "been the most difficult decision of my life." ${ }^{55}$ With Vice Chancellor von Papen by his side, these conditions, at least in the short term, largely moderated Hitler's more covert political agenda: purging Germany's Jews, rampant military conquest, and pan-European Lebensraum. ${ }^{56}$ Indeed, many around this point in time thought that Hitler-once renowned for his antisemitic tirades-had mellowed. ${ }^{57}$

Then in February 1933, the Reichstag was struck by arson-perhaps a Nazi orchestration ${ }^{58}$ - and subsequent events took an even more favorable turn in Hitler's direction. The Nazi Party blamed the fire on the revolutionary communists, a political group that just so happened to be in direct competition with the Nazis because they too promised 
to address Germany's long-standing class inequalities. Many Germans, Hitler among them, believed something had to be done to restore political stability and relieve the state from the threat of communist revolution. Whatever Hitler and the cabinet decided to do, von Hindenburg, the Wehrmacht, and Hitler's new friends in big business were unlikely to interfere-they too despised the communists. On 24 March 1933, the increasingly senile von Hindenburg supported the cabinet's introduction of the Enabling Act, an emergency law designed to protect the state against future communist threats. This act enabled the new chancellor to rule by decree for four years, thus setting the legal foundations of what would become a Nazi dictatorship. ${ }^{59}$ Having helped draft the decree, von Papen was not concerned by the Enabling Act's long-term implications, probably because his party dominated the all-powerful cabinet. However, as Saul Friedländer notes, although the Enabling Act required that all new legislative and executive decisions be discussed with the cabinet, real power fell increasingly to Hitler alone ${ }^{60}$ For so-called protective reasons, Hitler's henchmen began rounding up, detaining, and occasionally killing suspected communists in hastily constructed concentration camps. The mistreatment of these "terrorists" was widely supported ${ }^{61}$ only those within communist circles seemed concerned.

Not everything, however, went the Nazi's way. Although across the early 1930s Röhm successfully increased the SA membership to around four million, ${ }^{62}$ because von Papen pushed Hitler to estrange Röhm, the SA leader soon discovered he had been denied his revolution against rich Jews. An impatient Röhm and his SA leadership started initiating their own actions - the so-called second revolution-in the form of random acts of violence against wealthy Jews. ${ }^{63}$ These attacks, and Röhm's unwillingness to stop them, signaled to others that Hitler perhaps lacked control over factions within his own party. Before long, the increasingly rogue SA started to pose a threat to Hitler's tenuous hold on the chancellor's seat. Hitler, who believed the SA were acting like "fools and destroying everything..." 64 , needed to demonstrate to his new, yet wary, conservative friends that he retained total control. But to achieve this, Hitler also needed to show at least some support for the disgruntled Röhm. Hitler's fine balancing to resolve this problem involved his support for an SA-led nationwide boycott of Jewish businesses. The plan for this initiative was that the SA rank and file would inform prospective customers that the stores they were about to enter were owned by rich Jews. This information, the SA assumed, would discourage patronage and, 
starved of income, these businesses would be forced to close. Although Hitler's conservative coalition partners were not as radically opposed as he was to the Jews, they were still antisemitic. ${ }^{65}$ Thus, Hitler anticipated that von Papen and his powerful friends were unlikely to oppose a nationwide boycott of Jewish businesses, an initiative that might also placate the discontented Röhm.

Nazi Party radical Julius Streicher organized the boycott but failed to anticipate or did not care about its broader economic ramifications. The boycott, which began on 1 April 1933, precipitated a sudden slide in the German stock exchange. Most of the targeted businesses were financed by German banks, businesses that were themselves financed by national and international investors. Furthermore, because Germany's Jews only made up $1 \%$ of the national population, most of those working within these Jewish-owned businesses were non-Jews. As Jewish owners suffered, so too would their far more numerous employees. On the day of the boycotts, the public - to the surprise of the Nazi Party - reacted with a general indifference and occasionally obstinacy to the SA's information campaign. ${ }^{66}$ Not only did the boycott damage Germany financially, it had little impact on its target. In frustration, some zealous SA members responded violently to public obstinacy, but even these actions only served to harden the public's resolve. As the boycott began to have an effect on the broader economic structures, the Nazis' conservative allies became concerned-those people Hitler could least afford to rile. All plans for future initiatives were immediately and permanently shelved. ${ }^{67}$ For the Nazi regime, the boycott was a dismal and embarrassing failure.

This political blunder confirmed to Hitler that the most effective and realistic solution to "the Jewish question" lay not in violence, but in the gradual introduction and accumulation of antisemitic laws that, with time, would make daily life for Germany's Jews increasingly unbearable. If Jews encountered legally enforced discrimination at every turn, they might abandon all they owned and move elsewhere. A legal solution would sufficiently placate Hitler's most antisemitic supporters because it showed at least something was being done to remove Germany's Jews. And because mass Jewish emigration would open up new and lucrative business and employment opportunities, the Nazis' powerful conservative allies and many other Aryan welfare beneficiaries were unlikely to express any reservations.

On 7 April 1933, the Nazi Party introduced the Re-establishment of the Career Civil Service Act. This act determined that all German civil 
servants with at least one Jewish grandparent were to be dismissed. ${ }^{68}$ However, because von Hindenburg demanded the new law included exemptions for all Jews who had participated in or had family members killed during World War One, many Jewish civil servants managed to retain their government posts. Once again, Nazi attempts to undermine Germany's Jews had failed. ${ }^{69}$ Moreover, factions within the SA expressed their dissatisfaction with what seemed to them to be Hitler's soft legal solution. The SA continued to engage in sporadic acts of violence against Jews, ${ }^{70}$ and this hooliganism generated great unease among both Hitler's powerful conservative allies and the general public. And because these assaults typically traced back to Hitler's own inner ranks, the Führer decided to purge the more uncontrollable elements of the SA's leadership. In June 1934, inner-circle Nazis including Reichsmarschall Hermann Göring and SS-Reichsführer Heinrich Himmler organized to have Röhm and other rogue SA leaders assassinated during what has become known as the Night of the Long Knives. These assassinations - "the Third Reich's first mass murder" 71 - were in part designed to send a stern law-and-order message to the remaining SA rank and file. ${ }^{72}$ But this political purge extended into a broader power grab: Some of the targets included von Papen's own colleagues. The brazen plan worked. Soon afterward von Hindenburg died, Hitler pushed a nervous von Papen out of national politics. If the public was startled by these criminal acts of violence, leading political theorist and jurist(!) Carl Schmitt helped calm their nerves by arguing that actually mightmakes-right: "The Führer's deed was...not subordinate to justice, but rather it is itself supreme justice."73 Schmitt, it transpires, was far from the only prominent academic figure to provide reckless early support for Hitler and his clearly criminal regime-philosopher Martin Heidegger also helped the Party attain a level of high-society respectability. ${ }^{74}$ After Hitler himself successfully spun the murders in the media into an unfortunate yet morally necessary act, ${ }^{75}$ he then merged the offices of chancellor and president, assuming the new dual position himself. From this point, the Nazi Party held total dictatorial control of Germany. Claudia Koonz captures both the speed and enormity of Hitler's achievements:

In just over a year, he had mobilized ethnic populism to replace a constitutional democracy with a regime that could murder in the name of morality—and make its justification credible in the eyes of most Germans. ${ }^{76}$ 
With the removal of Röhm and other obstacles, Hitler was able to lay the foundations of what was at the time a politically more acceptable, legal-based solution to his Party's "Jewish question"-forced emigration. In September 1935, Hitler introduced the Nuremberg Laws, which, among other things, attempted to both define the Jews and prohibit their marriage to, and extramarital relations with, non-Jewish Germans. ${ }^{77}$ According to this hastily introduced law, a Jewish person was anyone with three or four Jewish grandparents. ${ }^{78}$ And because the Nazis had no definitive biological marker of Jewishness, the defining measure of a Jewish grandparent ended up being determined by baptismal records. ${ }^{79}$ Although clearly aimed mostly at the Jews, this law also applied to Germany's Gypsies. ${ }^{80}$

A year later, Göring was appointed to head the Four Year Plan (a national strategy of rearmament and self-sufficiency), a time frame that hinted at when Hitler intended to go to war in the pursuit of Lebensraum. ${ }^{81}$ The massive military preparations, in conjunction with the construction of about 1000 kilometers of Autobahn highway and numerous major public building projects in Berlin and Nuremberg, saw the rate of unemployment decrease. ${ }^{82}$ The ensuing economic recovery-financed by what Aly describes as "fiscally irresponsible" decisions to increase the national debt ${ }^{83}$-boosted the German public's confidence in their increasingly beloved Führer. As one passionate supporter, Helga Schmidt said, Hitler:

got rid of unemployment. Just about everybody had a job. He helped poor families with lots of children [who received] preferential coupons for foodstuffs, for clothing. They could buy them for less. Security for the population was restored. Crime disappeared completely. And, finally, the cultural amenities [also contributed to Hitler's popularity], like the Strength through Joy Program, inexpensive visits to the theater, and things contributing to the population's cultural life in general. That won a lot of support for him. ${ }^{84}$

In fact, from November 1933 the Nazi's Strength through Joy Program offered "deserving German workers" something never previously heard of before: cheap holidays abroad. ${ }^{85}$ Also new was that the Nazis made May Day, a springtime celebration honoring workers, a paid holiday. ${ }^{86}$ Middle- and upper-class Germans also did well: Between 1937 and 1939, the ownership of tens of thousands of cut-price Jewish businesses was transferred into the hands of no doubt delighted Aryans ${ }^{87}$ - some 
of whom did not even belong to the Nazi Party. ${ }^{88}$ Another first was that Hitler promised that automobiles would become affordable for all German families. ${ }^{89}$ With increased opportunities like these, it is perhaps of little surprise that Hans Dieter Schäfer argues that in the first six years of the Nazi regime, Gentiles were twice as likely to move up in German society as they had during the last six years of the Weimar Republic. ${ }^{90} \mathrm{By}$ 1939, there were more jobs than Germans could fill and 200,000 foreign workers were brought in to cover the shortfall. ${ }^{91}$ With things going so well under a strong dictator who genuinely seemed to care about every class of (Aryan) German, why bother going back to Weimar-like democracy marred, as it was, having emerged from a humiliating military defeat, followed by widespread (lower) class dissension, hyperinflation, political instability, and a crippling economic depression? ${ }^{92}$ This is why so many non-Jewish Germans described the peace period under the Nazis (1933-1939) "as a 'great time." "93 Too busy reveling in their own windfall, few if any of these lower- to upper-class Nazi welfare recipients stopped to contemplate who exactly was subsidizing their great times. ${ }^{94}$

The success of these and other achievements were also, in part, due to Hitler's management style. As Browning observes:

the Nazi system was composed of factions centered around the Nazi chieftains, who were in perpetual competition to outperform one another. Like a feudal monarch, Hitler stood above his squabbling vassals. He allotted 'fiefs' to build up the domains of his competing vassals as they demonstrated their ability to accomplish the tasks most appreciated by the Führer. ${ }^{95}$

Those who succeeded in converting Hitler's desires into reality were rewarded with larger projects and more power. And the fierce competition to please Hitler saw some of his more entrepreneurial underlings attempt to anticipate the Führer's desires and then, through their own great initiative, convert these suspected wishes into reality. ${ }^{96}$ As early as 1934, Werner Willikens, a state secretary in the Agriculture Ministry, realized how the new system worked:

everyone with a post in the new Germany has worked best when he has, so to speak, worked towards the Führer. Very often and in many spheres it has been the case...that individuals have simply waited for orders and instructions... but in fact it is the duty of everybody to try to work towards 
the Führer along the lines he would wish [...] But anyone who really works towards the Führer along his lines and towards his goal will certainly both now and in the future one day have the finest reward in the form of the sudden legal confirmation of his work. ${ }^{97}$

The German Foreign Office's Martin Luther provides an exemplary model of someone working toward the Führer's probable goals. Luther's meteoric rise up the Nazi ranks was, in part, due to his deployment of Carl Friedrich's rule of anticipated reactions (see Volume 1), where subordinates ask themselves "how would my superior wish me to behave?" Luther had an ability to anticipate from the bottom-up what his immediate superior, von Ribbentrop, needed before anyone else. And Luther was able to do so because, compared to his fellow subordinates, he could more accurately sense what Ribbentrop's boss- the Führerprobably top-down desired. ${ }^{98}$ During the Obedience studies, Williams, the experimenter, tended to engage in a similar "seizing the initiative from below in response to vague signals emanating from above..." 99 As the also "successful" Gestapo head Heinrich Müller explained to his men during World War Two, in the absence of written orders, they had to "get used to reading between the lines and acting accordingly." 100 The consequence was the introduction of a more modern horizontal, rather than top-down vertical, chain of command, where talented individuals from the lower ranks were free to pursue initiatives that could end up having a major influence on future policy. ${ }^{101}$ And the Führer greatly relied on the rule of anticipated reactions, as he said himself:

Where would I be...if I would not find people to whom I can entrust work which I myself cannot direct, tough people of whom I know they take the steps I would take myself. The best man is for me the one who bothers me least by taking upon himself 95 out of 100 decisions. ${ }^{102}$

Is it possible that Milgram, who was frequently absent from his laboratory, felt the same way about Williams? It transpires that Hitler's handsoff management style could also prove politically expedient. Should any of his underling's initiatives fail or even end up embarrassing the party, the Führer could always distance himself from personal responsibility because he never explicitly made such demands. And if Hitler (apparently) had no knowledge of such initiatives, he could rather conveniently claim plausible deniability, thus evading any political fallout. ${ }^{103}$ 
One area where competition in anticipating the Führer's desires remained intense was in the resolution of the all-important "Jewish question." On this issue, two main factions existed. On the one hand, there were those termed the "realists" who favored legislative changes that promoted forced emigration ${ }^{104}$ and on the other were those termed the "strong believers," 105 including party radicals like Julius Streicher (editor of the antisemitic publication Der Stürmer-The Stormtrooper) and Joseph Goebbels (head of the Ministry of Public Enlightenment and Propaganda). The strong believers thought that emigration of so-called inferiors to just beyond the Reich's geographical border would only enable them to reproduce and would do nothing to eliminate their potential future threat. Thus, when it came to the "Jewish question," they believed sterilization or even extermination was the only permanent solution. ${ }^{106}$ At this early stage, Hitler favored a policy of forced emigration, probably because it had already shown itself to be more "realistic." Two particular events, both in 1938, reinforced this preference: the Kristallnacht pogrom and the annexation of Austria.

During the summer of 1938, the Évian Conference was held in France. The aim of this meeting of political heads and various nongovernmental organizations was to explore the possibility of other countries accepting Germany's unwanted Jews. However, the talks soon stalled because the German government refused to give assurances that Jewish refugees could migrate with sufficient capital with which to start new lives abroad. ${ }^{107}$ So, even when Jews were willing to leave Germany, without capital - which the Nazi regime had frozen-most other nations in the wake of a post-1929 financial crisis refused to accept them or, at best, only small numbers. The failure of this conference ensured that most German Jews found themselves stuck in a country whose government did not want them. In frustration, the Nazi regime forced some Polish-born Jews living in Germany back to their homeland. However, the Polish government refused to accept them, arguing that because they had lived in Germany for so long, they were now German nationals. This border dispute rendered these Jews stateless refugees. On 7 November 1938, a desperate Jewish teenager, whose parents happened to be caught in this border dispute, reacted by assassinating a German embassy official in Paris. In revenge, Goebbels convinced Hitler to allow him to organize a nationwide pogrom aimed at Germany's Jews. ${ }^{108}$ Goebbels was probably trying to capitalize on the assassination as a 
means of promoting antisemitic sentiment within Germany and to claw back some of the power he and other "strong-believers" had lost to the "realists." The pogrom became known as Kristallnacht (night of crystal, or the "Night of Broken Glass"). Largely at the hands of Nazi Stormtroopers, on 9-10 November nearly 300 synagogues were burned down, hundreds of Jewish-owned businesses were vandalized and looted, and, like the communists before them, thousands of Jews were rounded up and sent to concentration camps. The pogrom ended in about one hundred Jewish fatalities.

Because pogrom-like violence of this scale had not been seen in industrialized Western Europe for such a long time, ${ }^{109}$ Kristallnacht was a watershed event. But the pogrom also generated a variety of unforeseen problems for the Nazi regime. First, it led to the destruction of Jewish property that happened to be insured by German and international firms. Second, the chaos surrounding the pogrom sent more shock waves of fear through the volatile German stock exchange. And finally, again to the regime's surprise, the ensuing disorder disgusted significant sectors of German society. ${ }^{110}$ These problems rendered Goebbels' pogrom a complete political disaster and thus further reinforced the realist position. ${ }^{111}$

Simultaneously, another major event bolstered Hitler's view that mass emigration offered the most likely "successful solution" to his Party's "Jewish problem." In pursuit of Lebensraum and to unify "all persons of German blood," the Wehrmacht annexed Hitler's homeland of Austria on 12 March 1938. Doing so meant Germany inherited Austria's 200,000 Jews $^{112}$ _ even more Jews than the Nazis had been able to push out of Germany. ${ }^{113}$ Soon afterward, one of Himmler's low-ranking Nazi bureaucrats, Adolf Eichmann, developed an "assembly-line technique" to increase the efficiency of the Austrian government's Jewish emigration application process. ${ }^{114}$ As Eichmann explained after the war, "an idea took shape in my mind: a conveyor belt. The initial application and all the rest of the required papers are put in at one end, and the passport falls off at the other..." 115 Within six months, Eichmann's organizational process resulted in the deportation of one-quarter of all Austria's Jews. Eichmann's "realist" superiors could boast of this great success in contrast to the disastrous Kristallnacht pogrom. According to Karl Schleunes, the simultaneous failure of Kristallnacht and Eichmann's success caused a pivotal power shift within the upper echelons of the Nazi hierarchy: 
The year 1938 is marked...by.... trend towards centralization of control over Jewish policy. In part this trend reflected the newly found powers of Goering, Heydrich, and Eichmann; in part it reflected the final failure of the emotional antisemitic wing of the Nazi movement to produce a solution to the Jewish problem through pogroms. The failure of the November pogrom finally discredited the impulsive radicals and strengthened the hand of the realists whose work in 1938 promised a more effective solution through bureaucratic means. Most important of all, Hitler finally made a choice between these two approaches to the Jewish issue. ${ }^{116}$

As efficient organizational means to the desired political end were introduced, the "hoodlums were banished and the bureaucrats took over."117 The "Göring-Himmler-Heydrich alliance,"118 with the support of Eichmann's effective organizational skills, gained supremacy in dealing with the "Jewish problem," wherever it might lead. Once Göring had been placed in charge, he delegated responsibility to SS-Obergruppenführer Reinhard Heydrich, who, on 24 January 1939, authorized the opening of the Reich Central Office for Jewish Emigration. ${ }^{119}$ Heydrich instructed that Eichmann's more efficient approach to mass emigration was to be applied in all of Germany's larger cities. $^{120}$

While Hitler's actions signified his support for the "realists," however, his rhetoric still tended to reflect the views of the "strong believers." 121 In a 30 January 1939 speech, he stated:

In my life I have often been a prophet, and I have mostly been laughed at. At the time of my struggle for power, it was mostly the Jewish people who laughed at the prophecy that one day I would attain in Germany the leadership of the state and therewith of the entire nation, and that among other problems I would also solve the Jewish one. I think that the uproarious laughter of that time has in the meantime remained stuck in German Jewry's throat. [...] Today I want to be a prophet again: If international finance Jewry inside and outside Europe again succeeds in precipitating the nations into a world war, the result will not be the Bolshevization of the earth and with it the victory of Jewry, but the annihilation of the Jewish race in Europe. ${ }^{122}$

Because of Hitler's circa 1930 public relations makeover from vitriolic Jew baiter to reflective political visionary, the above statement was 
actually one of only three occasions between 1933 and 1939 where the Führer publicly expressed his racial hatred of the Jews. ${ }^{123}$ Then, just over a month later in March 1939, Hitler certainly did his bit to encourage such a war when his troops annexed all of Czechoslovakia (including the Sudetenland). Because, in this case, the Nazis could not rely on their usual late 1930s justifications for annexing other nations' territories-like their repossessing of land "stolen" as a result of the Treaty of Versailles or coming to the aid of German settlers "suffering" at the hands of nations just beyond Germany's border-Hitler's actually far broader covert ambitions to annex more living space became, for the first time, undeniable. ${ }^{124}$ On a pan-European scale, it was clear that Hitler was, first and foremost, aggressively in pursuit of Lebensraum.

When Hitler made his threat to annihilate European Jewry, it probably appeared to inner-circle Nazis as pure posture. His actions clearly supported the "realist" policy of forced emigration (and he had previously threatened the lives of German Jews, obviously with no follow-through). However, such threats were in all likelihood both posture and genuine. Posturing, because even if the Nazis gained total control of Europe sometime in the future, they had neither the strategy, nor the infrastructure, nor the technology-no procedure - to render them capable of exterminating such massive numbers of mostly women and children. Hitler's position here in some ways resembles Milgram's before the pilot studies: The Führer had a preconceived goal but, at that point in time, no procedure capable of converting it into a reality. Nonetheless, the point is that for Hitler, annihilation was and would remain for some time impossible.

Even so, his threats were not completely hollow. Although a means of massacring massive numbers of civilians did not then exist, Hitler's past experience hinted at the possibility that, with time, it could possibly be invented. As a courier in the Wehrmacht during World War One, Hitler had participated in about fifty battles. ${ }^{125} \mathrm{He}$ had experienced trench warfare firsthand during the Battle of the Somme, which had killed or wounded more than a million men in less than six months. ${ }^{126}$ Many other high-ranking Nazis had also experienced the incredibly destructive power of modern warfare. If death on such a massive scale were possible in one context, why not in another-just change the target and obtain the same end result? Bartov argues: 
while there is clearly a distinction to be made between the mutual killing of soldiers and the wholesale massacre of defenseless populations, it is crucial to realize that total war and genocide are closely related. For modern war provides the occasion and the tools, the manpower and the organization, the mentality and the imagery necessary for the perpetration of genocide. With the introduction of industrial killing to the battlefield, the systematic murder of whole peoples became both practical and thinkable: those who had experienced the former could imagine and plan, organize, and perpetrate the latter. ${ }^{127}$

In fact, almost two decades earlier in Mein Kampf, Hitler had envisaged the application of the then-latest military technology to resolving his score with the Jews, suggesting that 12,000-15,000 "Hebrew corrupters" be "held under poison gas..." 128 And historical events informed Hitler that other nations during wartime had managed to exterminate massive numbers of unwanted civilians. As we shall see, just over six months after making the above (January 1939) threat, Hitler acknowledged awareness of the Armenian genocide by the Turks and had long "admired" the US extermination of its indigenous population. ${ }^{129}$ As Germany, perhaps the most technically advanced nation in the world, ${ }^{130}$ approached the mid-twentieth century, who really knew what might be possible under the cover of war. Perhaps war and genocide could be part of a single Nazi ideological program. Just as Milgram would use the Holocaust as an initial guide to envisage a basic experimental procedure, Hitler used previous genocides and wars to image exterminating the Jews.

Nevertheless, until 1939 all signals suggested to the "realist" in Hitler that extermination remained impossible and Jewish emigration the more practical alternative. But the "strong believer" in Hitler knew that displacing "inferiors" beyond the border would not eliminate their perceived threat. And therefore a realistic strategy capable of mass extermination is, in all likelihood, what he ultimately desired. After all, underlings referred to the annihilation of European Jewry as "the Führer's wish"-something desired but like most wishes, probably unobtainable. ${ }^{131}$ For "realist" bureaucrats-Eichmann, his superior Reinhard Heydrich, and his superior Heinrich Himmler-who all worked competitively on the Jewish question, more power awaited those who could convert the Führer's wish into reality. 


\section{The Change from Conventional Positive to Radical Negative Eugenics}

How, it must be asked, could Hitler have felt so comfortable publicly threatening all of European Jewry just two months after many German "onlookers" had shunned the violent Kristallnacht pogrom? Perhaps these onlookers were more disgusted with the disorder than the terrifying experiences of the Jewish targets. ${ }^{132}$ Somewhat related to this, it is fairly clear that by the eve of World War Two, public support for or indifference to Nazi ideology and negative eugenics had increased. And it appears that the German public's increasing sympathy for or general indifference to the Nazi's radical worldview can, as the following argues, largely be attributed to systemic forces-the Nazi ascendency to power, and more specifically, their total control over state finances. That is, after the Nazis rose to power, they gained monopolistic control over Germany's "informational and social field."

On assuming power, and especially after the formalization of the 1935 Nuremberg Laws, the Nazi regime instituted a policy to fund the research only of those members of the German intelligentsiaacademics and scientists-who were willing to become National Socialists. ${ }^{133}$ This contractual clause inadvertently ensured that those most likely to obtain government funding were sympathetic to Nazi ideology or careerists who, concerned with their financial or social security, would tow the party line. ${ }^{134}$ Both groups could be counted on to provide the Nazi regime with scholarly data that at least did not conflict with or, even better, bolstered the party's radical belief system. Beyond funding, other benefits for producing ideologically congruent research included rapid promotion, new employment opportunities, fellowships, lecture tours, accolades, press conferences, intensified media coverage, and selection to sit on prestigious editorial boards. ${ }^{135}$ In fact, to uncover the latest findings in racial research, throughout Germany five multi-disciplinary antisemitic research institutes were createdwhat we today would call think tanks. ${ }^{136} \mathrm{~A}$ number of German biologists, theologians, psychiatrists, and anthropologists-for example, Max Hildebert Boehm, Paul Brohmer, Eugen Fischer, Gerhard Kittel, Robert Ritter, Carl Schneider, Peter-Heinz Seraphim, and Otmar Freiherr von Verschuer-not only politically supported the Nazis, most if not all ended up producing research that reinforced the party's racist and ableist ideology. While this "veritable academic industry" thrived, ${ }^{137}$ it was no 
coincidence that all of these figures, to some degree, personally benefited. ${ }^{138}$ Although the ideologically congruent researchers only made up a minority of the academy, because the regime tended to shower them with attention, they appeared to be far more representative than they actually were. ${ }^{139}$ Thus, not only did most tenured professors refuse to play ideological ball, as long as they kept their criticisms to themselves, they were not punished. They were, however, excluded from receiving all the benefits that happened to be on offer. ${ }^{140}$ As the scholarly silent majority sat back and watched some of their colleagues rewarded for publishing fraudulent and grossly flawed research, their resentment must have been palpable. Although the Nazi regime injected large amounts of funding into discovering an irrefutable physiological means of distinguishing Jews from others, no robust marker-blood type, nose shape, skull size, or fingerprint pattern-was ever found. ${ }^{141}$ As scholars in the natural sciences quickly tired of ever finding such a marker, a small yet influential group of social sciences and humanities researchers continued to unravel the (apparently) latest distinctive characteristics of Jewish culture. ${ }^{142}$

Another understandably very small group of scholars were distinguishable because they not only vociferously challenged their colleague's pro-Nazi research, they also attacked the intellectual foundations of Nazi ideology. For this, their career trajectories, relative to the ideologues, moved in the very opposite direction. Consider, for example, Karl Saller, an anthropologist at the University of Munich, who "attacked the concept of a fixed Nordic race and said that modern Germans were racially mixed. Reinhard Heydrich banned him from teaching. Saller lost his chair at Munich. His fellow university teachers did not protest, instead they started to avoid him." 143 Those scholars who refused to join the Nazi Party, or worse, like Saller, publicly challenged the regime's beliefs, were forced to take their dissenting voices elsewhere or were silenced through imprisonment or execution. ${ }^{144}$ The insights of these critics, as Glover notes, "spread round the world, sometimes posthumously, sometimes through their writing and teaching in exile." Most importantly, "they were no longer there, in German and Austrian universities, to ask the necessary questions." 145 Germany as a whole was thereby diverted from exposure to these alternative and intellectually more rigorous perspectives. ${ }^{146}$ Sustaining the Nazi's blinkered worldview was that between 1933 and 1934 about 1600 Jewish academics were fired and replaced with no doubt grateful and predictably compliant "Aryan" professors. ${ }^{147}$ For both 
the new and remaining non-Jewish scholars, the message was clear: Hitler refused "to accept disagreeable information" and this intransigent worldview would be "a dominant feature of his style of government." 148

Germany's police, whose job it was to uphold the barrage of new and intensifying antisemitic laws, underwent a similar but probably intensified ideological filtering process. ${ }^{149}$ In fact, during recruitment drives, prospective officers who had joined the Nazi Party before 1933 were deemed preferable over those who had not. ${ }^{150}$ The effects of this filtering process accelerated greatly when in 1936 the uniformed police were subsumed by Himmler's Nazi SS-Hitler's elite paramilitary guard. The ideologically driven merger also saw the militarization of law enforcement across Germany. ${ }^{151}$

The primary and secondary teaching professions were also purged of all "undesirables"-Jews and critical Leftists. ${ }^{152}$ There too, career advancement became near impossible without party membership. ${ }^{153}$ Although only a third or quarter of teachers were ardent Nazis, ${ }^{154}$ by 1936 all teachers working for the German government had joined the Nazi Party, ${ }^{155}$ and more than two-thirds of them started attending "twoweekly "retreats" where they were familiarized with the application of Nazi ideology. ${ }^{156}$ Because only a minority of them were strong believers, Koonz notes that the means of advancing Nazi doctrine at these teacher retreats was purposefully subtle-less explicitly racist and ableist, and more about promoting a positive affect toward "national pride," "ethnic solidarity," and [healthy white] egalitarian "we-consciousness..."157 The broad and insidious consequence of this multi-pronged employment process across the academic, police, and teaching professions was that only committed ideologues, opportunists, and those fearing conflict with the party ended up filling the most influential leadership posts. Despite the varied approaches of these different professional groups when dealing with the Nazi party, the outcome was the same: All their overt criticisms against the regime essentially evaporated.

For Aryans, more employment and advancement opportunities followed when Goebbels eliminated all Jewish influence from the press, radio, publishing houses, and film industry. ${ }^{158}$ This policy stripped Germany's Jews of any opportunity to publicly respond to their mistreatment or to appeal to the sympathies of the wider public. Then again, it was not as if the Jews or anyone else for that matter could complain because as early as 1934 the Nazis had introduced laws like the Heimtückegesetz, which banned all political slander and critical dissent 
against them. ${ }^{159}$ And as early as 1933, Party headquarters started sending infringement notices to non-Jewish Germans observed maintaining social relations with Jews. As one person who had received three such infringement notices told a friend married to a Jewish woman, their "pleasant chats...must unfortunately cease." 160 Nor were these threats empty: It got to the point where just showing kindness to Jews could result in arrest. ${ }^{161}$ Some people who were previously "anything but a Nazi" started, for example, wearing swastika lapel pins. They did so not because they had been politically converted, but because doing so circumvented suspicions of them being political agitators. ${ }^{162}$ Fearful or simply jaded into submission, the socially easiest path for those personally critical of the Nazi's discriminatory measures was silence.

Drawing on Luhmann's scholarly legacy, Stefan Kühl argues that most Germans' silence to the Nazi's antisemitic legal assault generated an antisemitic "fictional consensus..."163 This antisemitic fictional consensus was the false perception among most Germans that-because Goebbels flooded the media with images of massive crowds of Germans captivated by Hitler's every word ${ }^{164}$-the Nazi's racial policies must have been unanimously popular. The perception surrounding the popularity of the Nazi's discriminatory policies also had a powerful controlling influence on most German's everyday social interactions. That is, with time Germans assumed that their fellows would react with universal approval to their overt support for the Nazis and universal disapproval to any criticism they might have of the regime. So those Germans who personally disagreed with the regime's treatment of "inferiors" felt an intensifying pressure to keep such views to themselves, thereby securing their critical silence. ${ }^{165}$ Importantly, Kühl adds that the critical silence, however, only ended up fueling the antisemitic fictional consensus because this apparent consensus was founded on the "untested assumption" that everybody else agreed with the Nazi's legal assault. ${ }^{166}$ Others, like Uwe Storjohann, captured the essence of this fictional consensus, describing Germany under the Nazis as a "nationally stable union of non-understanders, keep-quieters, head-nodders, deaf-ear- and blindeye-turners..."167 And if the Jewish community themselves never complained about their advancing social and legal isolation (they of course couldn't), perhaps, in the minds of the unreflective majority, the Jew's hardships were perhaps not all that harsh after all.

Anyway, across the second half of the 1930s the Nazi intellectuals' (pseudo) scientific research, in conjunction with additional Nazi 
spin, was injected into the national educational curriculum, ${ }^{168}$ newspapers (particularly Streicher's "semi-pornographic" Der Stürmer and Walter Gross's more "breezy middlebrow" Neues Volk (New Volk)), ${ }^{169}$ Nazi youth organizations, ${ }^{170}$ exhibitions, ${ }^{171}$ and movie productions. Consider, for example, the National Socialist Office of Racial Politics and their mid-1930s production of a variety of documentary films with titles like The Sins of the Fathers, Sins against Blood and Race, and Palaces for the Mentally Ill, all of which subtly contrasted "degenerate[s]" with healthy athletic Nordic types. ${ }^{172}$ Then in 1940, the German film industry released their two most infamous antisemitic movies: Jud Süss (Jew Suess) and Der ewige Jude (The Eternal Jew). As Friedländer notes, the aim of these subsidized films was the same, "to elicit fear, disgust, and hatred." 173 Although Der ewige Jude was a flop, ${ }^{174}$ in just a few years Jud Süss, a movie that repeats verbatim Martin Luther's violent solution to the "Jewish question" had been viewed by 20.3 million Germans. ${ }^{175}$ As one viewer noted, "The Jew is shown here as he really is [...] I would have loved to wring his neck."176 For some viewers, the movie clearly had its intended effect. The fact that criticizing Jud Süss was illegal makes Goebbels' reaction to its launch somewhat farcical: "The film is a wild success. One hears only enthusiastic comments" and "Everybody praises the film to the skies..."177

So around the start of World War Two, it appears a relentless propaganda machine in the near absence of any conflicting information persuaded many ordinary Germans that a society without "inferiors" would probably be good for the Reich. ${ }^{178}$ As Oskar Gröning, an SS administrator later stationed at Auschwitz, put it, "We were convinced by our worldview that there was a great conspiracy of Jewishness against us..."179 Therefore, during the early 1940s, Gröning "carried on working at Auschwitz not just because he was ordered to but because, having weighed the evidence put before him, he thought that the extermination program was right."180 As the more directly involved perpetrator, Kurt Möbius admitted:

We police went by the phrase, 'Whatever serves the state is right, whatever harms the state is wrong.' I would also like to say that it never even entered my head that these orders could be wrong. Although I am aware that it is the duty of the police to protect the innocent I was however at that time convinced that the Jewish people were not innocent but guilty. I believed all the propaganda that Jews were criminals and subhuman [Untermenschen] and that they were the cause of Germany's decline after the First World War. ${ }^{181}$ 
Because, as we shall see, the Nazi regime socially constructed Jews as partisans and crooks, morally self-righteous killers like Möbius really did perceive "themselves as the executors of state measures taken against killers, murderers, and criminals." 182 For Möbius and many others, the German people were (apparently) victims of various injustices, and it was these kinds of iniquities that helped fuel what developed into an unwavering and unreflective pursuit of self-righteous revenge. Although the Nazi's insidious social engineering program aimed to, at least, secure the wider German public's indifference to the fate of German Jewry, for some, as the above comments illustrate, it potentially paved the way for something proactively far more radical. And this purposefully calculated (mis)information campaign also went further than converting the removal of Jews and other inferiors into a social good-those Germans who chose to maintain friendly relations with so-called inferiors would, as Müller-Hill implied earlier, be responsible for destroying advanced Germanic civilization. ${ }^{183}$ So not only was previously bad behavior morally inverted into a social good, what was once considered good was reconfigured into something really bad. ${ }^{184}$ One of the Nazi's greatest obstacles during their intense propaganda campaign was that, as De Swaan points out, many Germans had been exposed to other religious, educational, and familial moral codes. Consequently, "[ $\mathrm{t}] \mathrm{hey}$ were not completely devoid of a moral sense..." And, much like during the Obedience studies, when insufficiently indoctrinated people were faced by intense moral dilemmas, "inner conflict $[\mathrm{s}]$ " could plague their conscience. ${ }^{185}$

In summary, the cumulative consequence of the Nazi's social engineering program was that over time sectors within the German intelligentsia, teaching profession, and entire security apparatus (among other groups) contributed to and helped reinforce the regime's self-imposed "ideological echo chamber..."186 From every direction within this chamber, German society was encouraged to believe that they were the master race and that in order to save advanced Germanic civilization, something monumental needed to be done about the impending threat posed by those of inferior blood. Again, because all the normally credible and authoritative societal voices explicitly or passively seemed to agree with Hitler, then, in the eyes of ordinary Germans, perhaps Nazi ideology was not all that radical after all. In fact, for many Germans the Nazis provided a unique form of political leadership: Only they were willing to stand up and protect all that was good and great, unlike all those "liberal-pacifist" fools elsewhere in the world who not only paved the way 
for the destruction of superior Aryan blood, but had even been duped into spending "great sums of money" to protect "criminals and mentally deranged" inferiors. ${ }^{187}$ It was for this reason, as Neitzel and Welzer astutely observe:

the entire collection of events known as the "Third Reich" and the violence it produced can be seen as a gigantic experiment, showing what sane people who see themselves as good are capable of if they consider something to be appropriate, sensible, or correct. ${ }^{188}$

As Roy Baumeister argues, when the world is viewed through the average German's eyes during the lead up to World War Two-we are morally good, others are degenerate and evil ${ }^{189}$ - Nazi ideology no longer appears, as many see it today: the epitome of evil. Instead, when German citizenry's carefully manufactured and purposefully blinkered worldview is considered, their movement toward an increasingly violent solution becomes both terrifyingly logical and comprehensible. ${ }^{190}$ Led by an apparent "fearless crusader for justice," many of those working within the Nazi regime genuinely came to believe they were pursuing the morally right, even righteous path. ${ }^{191}$ And if there had been some potential merit to this inherently supercilious belief system - those of the Jewish faith, Gypsies, Eastern Europeans, and those with disabilities really did pose a genetic, social, and cultural threat to "advanced" Western civilization-then in the name of free speech, perhaps such issues merited public debate. But the problem was not just that they were wrong, the intractable Nazis had no interest in, and even actively went to enormous lengths to avoid, exposure to conflicting critical views. They simply could not bear to have the validity of their bigoted worldview challenged and then demolished by more informed critics like Karl Saller. And that most Germans were socially, financially, and materially doing so well under the Nazis only rendered this majority more receptive or at least amenable to Hitler's covertly destructive political agenda. Thus, overarching structural forces (the legal assault, selective employment practices, and the Nazi's self-imposed "ideological echo chamber") along with the showering of various self-interested benefits likely played a crucial role in many German's avid support for or indifference toward the Nazi regime's increasingly radical and destructive ambitions. Furthermore, because each change the Nazis introduced was, on its own, small and therefore seemingly insignificant, with time their many little changes added up to the point that German society was imperceptibly blunted to the reality that, in the spirit of shifting baselines, "fundamental change" had taken hold. ${ }^{192}$ 
This was the subtle, creeping, and cumulatively effectual (mis)information process that rendered many Germans in favor of or indifferent to the Nazi's radical negative eugenics-based social policies, whatever exactly they ended up entailing. The key achievement of the Nazi's social engineering was that many so-called inferiors were moved beyond "the boundaries of the universe of obligation..." 193 It was therefore implied to the German citizenry that as far as their government was concerned, whatever hardships might befall the Jews and other "sub-humans," they need not fret over it. These people simply no longer mattered. And should, in the near future, the Nazi regime instruct those in the German armed forces to harm these "inferiors," by the late 1930s such a request was no longer outside but tentatively within the parameters of one's expected duties. That is, as Kühl convincingly argues, as the start of World War Two approached, the Nazi propaganda machine ensured that many members in the German armed forces were likely to "view an order to kill as an expectation within the framework of their organizational zone of indifference."194 Furthermore, because "the systematic disenfranchisement of the Jews had" by this point in time, "progressed so far that not a single member" of the German armed forces in the soon to be occupied territories "had to worry about being punished by the authorities if they assaulted Jews in violation of the applicable laws and regulations." 195 Thus, as the start of the war approached, these men would have sensed that if Germany proved victorious, they could-if they so chose-very likely assault "inferiors" with total impunity.

\section{The Nazi Decent into World War Two}

As mentioned, to reverse all those past injustices like the Treaty of Versailles and perhaps, in the process, make Germany even greater, central to Hitler's covert ideological vision was that Germany go to war. In pursuit of Lebensraum, in March 1939 Hitler started to plan an invasion of Poland. First, the Wehrmacht would attack Poland from the west, and by prior arrangement, the Soviet Union would invade Poland from the east. After defeating Poland, the invaders intended to split the spoils with the western half going to Germany and the Soviets gaining the eastern half. The Nazis anticipated that Poland's leadership class-politicians, intellectuals, and government officials-were likely to encourage their citizenry to resist German hegemony. Hitler, therefore, believed that securing Polish docility necessitated this group's elimination. Fearing 
high-ranking members of the Wehrmacht might resist Hitler's desires, Heydrich and others were charged with forming the Einsatzgruppen, a paramilitary force. The Einsatzgruppen consisted of about two thousand carefully selected SS men who, according to SS-Brigadeführer Werner Best, were chosen on the grounds that they were likely to work "ruthlessly and harshly to achieve National Socialist aims..."196 Lothar Beutel (one of the commanders) said that Heydrich told the Einsatzgruppen leadership on 18 August 1939 that as far as the Polish resistance movement and its leaders were concerned, "everything was allowed, including shootings and arrests." 197 Heydrich also supplied the Einsatzgruppen with a list of 61,000 Polish Jews and Christians who were believed to be members of "anti-German” groups. ${ }^{198}$ Four days after Heydrich's speech to the Einsatzgruppen leadership and just over a week before the invasion, on 22 August 1939, Hitler informed his top military commanders:

Our strength is in our quickness and our brutality. Genghis Khan had millions of women and children killed by his own will and with a gay heart. History sees only in him a great state builder. [...] Thus for the time being I have sent to the East only my "Death's Head Units" with the order to kill without pity or mercy all men, women, and children of Polish race or language. Only in such a way will we win the vital space that we need. Who still talks nowadays of the extermination of the Armenians? 199

But why would Germans agree to pursue such premeditated plans to annex Polish territory and kill its citizenry-how could they support such blatant skulduggery that might put their own lives at risk? As Göring said after World War Two, kindling the German people's support for the Polish invasion was, for the Nazi regime, a minor obstacle:

Why, of course, the people don't want war [...] Why would some poor slob on a farm want to risk his life in a war when the best that he can get out of it is to come back to his farm in one piece. Naturally, the common people don't want war; neither in Russia nor in England nor in America, nor for that matter in Germany. That is understood. But, after all, it is the leaders of the country who determine the policy and it is always a simple matter to drag the people along, whether it is a democracy or a fascist dictatorship or a Parliament or a Communist dictatorship. [...] voice or no voice, the people can always be brought to the bidding of the leaders. That is easy. All you have to do is tell them they are being attacked and denounce the pacifists for lack of patriotism and exposing the country to danger. It works the same way in any country. ${ }^{200}$ 
Indeed, on Hitler's orders, the SS intelligence service fabricated an attack by the Polish military on a German radio station proximate to the shared border. ${ }^{201}$ This pretense, as Göring put it, proved sufficient in securing public support for the Polish invasion. For the invading German forces, this attack secured "a belief in the justice of conquest..."202 Bolstering this pretense was the belief common among those like Hitler that when colonizing other nations it is "morally acceptable-especially in wartime-to extinguish 'lower' civilizations that stood in the way of 'progress." 203 And should any of the inferiors prove lucky enough to survive the onslaught, the colonizer would then bestow on them the (apparently) invaluable gift of a "higher" civilization. Whatever the outcome of the colonizing feat, the invaders would rather conveniently end up reconfiguring their destructive aggression into an all-round social good.

\section{Conclusion}

This chapter outlined, within the democratic state of Germany, the disconcerting rise and increasing popularity of Adolf Hitler and his Nazi Party. The Party's political ascendency was largely due to a combination of the cunning political strategy of appealing to the desires of all Germans and an uncanny ability to capitalize on every bit of luck that fell their way. Although already effective with so little, when the Party ascended to power and accessed the enormous resources of the German state, Goebbels seized this opportunity to promulgate the Nazi's ideological vision by, as Milgram would put it, restructuring the social and informational field. The Nazis seductively appealed to the inferiority complex that happened to lie at the heart of the average non-Jewish German: "Aryans" are genetically superior, a master race is entitled to more than others, and, in a quest to make Germany great, the Nazi Party intended on giving Germans all they (apparently) deserved. Across Germany, the Nazi's expansionist ideology and contempt for so-called inferiors spread. This imperialist vision of grandeur and the general disdain (or indifference) it engendered toward "subhumans" proved infectious. Within many Germans, the dark side of this infection expressed itself in the form of vanity, hubris, and a militaristic yearning for a united omnipotent Germany to, much like during the nineteenth century, dominate.

The success of Goebbels' social engineering program was largely due to the Nazi Party's structural and systematic elimination of dissenting 
and simultaneous concentration of consenting "expert" public voices. For many ordinary Germans, the Nazi Party seemed to know the best way forward-anybody who was somebody said so and nobody seems to disagree. And as the Nazi's imperialist ambitions and their unrelenting disparagement of the infectious "other" spread, simultaneously the average German became socially, financially, and materially better off, albeit typically at the expense of those "others." 204 The prospect of reaching the top proved too irresistible for many. Blind faith in their intensely antisemitic Führer soared and many Germans, with a "well-developed calculating instinct for their private interests," 205 decided they would follow him wherever he might lead them.

\section{Notes}

1. Milgram (1974, p. 7).

2. Quoted in Landau (1994, pp. 46-47).

3. Browning (2004, p. 4).

4. Quoted in Wistrich (2001, p. 1).

5. Glover $(1999$, p. 195).

6. Quoted in Friedlander (1995, p. 4).

7. van Pelt and Dwork (1996, p. 62).

8. Quoted in Glover (1999, p. 195).

9. Kühne (2010, p. 15) and Aly (2006, p. 32).

10. Kühne (2010, p. 15).

11. Binding and Hoche (1920, as cited in van Pelt and Dwork 1996, p. 63).

12. Baur et al. (1921).

13. Quoted in Rubenstein and Roth (1987, p. 141).

14. Friedlander (1995, p. 8).

15. Rubenstein and Roth $(1987$, p. 141).

16. Between 1907 and $1945,45,127$ people were sterilized in the USA (Koonz 2003, p. 105). As we shall see, in just a few years the Nazis sterilized far greater numbers of Germans (see Lifton 1986, pp. 24, 27).

17. Traverso $(2003$, p. 122).

18. Friedlander (1995, p. 18) and Müller-Hill (1988, p. 28).

19. Quoted in Kevles (1995, p. 116, as cited in Klautke 2016, p. 26).

20. Hitler ([1925] 1943).

21. Quoted in Wistrich $(2001$, p. 34).

22. Kühne (2010, p. 34) and Neitzel and Welzer (2012, p. 32).

23. Quoted in Burleigh and Wippermann (1991, p. 42).

24. Aly (2006, p. 13).

25. Quoted in Friedländer (1997, p. 75). 
26. See, for example, Fest (1974, p. 37).

27. Lukacs (1997, pp. 65-75, as cited in Breitman 2000, p. 13).

28. Kühne $(2010$, p. 16).

29. Friedlander $(1995$, p. 13).

30. Müller-Hill (1988, p. 22).

31. Quoted in Waite (2000, p. 176).

32. Browning $(2004$, p. 10$)$.

33. $\operatorname{Koonz}(2003$, p. 9$)$.

34. Rossino (2003, p. 2).

35. Hitler (1940, pp. 67-100, as cited in Rutherford 2007, p. 55 ).

36. Wistrich $(2001$, p. 38$)$.

37. Arendt (1958, pp. 121-267) and Browning (2004, p. 14).

38. Hitler (2013, p. 28).

39. Wistrich (2001, p. 44).

40. Longerich $(2010$, p. 16).

41. Longerich $(2010$, p. 17).

42. Koonz (2003, p. 27).

43. Koonz (2003, p. 70).

44. Quoted in Koonz (2003, p. 75$)$.

45. Koonz (2003, p. 18). As Hitler said in Mein Kampf (quoted in Koonz 2003 , pp. 17-18), the orator "can always see in the faces of his listeners..." and can use these cues to determine the destination of a warmly received speech: "The speaker will always let himself be borne by the great masses in such a way that instinctively the very words come to his lips that he needs to speak to the hearts of his audience. If he errs ... he has the living correction before him."

46. Behrenbeck (1999, p. 336, as cited in Neitzel and Welzer 2012, p. 36).

47. Neitzel and Welzer (2012, p. 36).

48. Kühne $(2010$, p. 14).

49. Wistrich (2001, p. 44).

50. Kühne $(2010$, p. 34$)$.

51. Breitman (2000, p. 17).

52. Wistrich (2001, p. 44).

53. Bauer (2001, p. 32$)$.

54. Schleunes (1970, pp. 68-69).

55. Quoted in Koonz (2003, p. 33).

56. Koonz (2003, p. 79).

57. See Koonz (2003, p. 31).

58. See Hett (2014).

59. van Pelt and Dwork (1996, pp. 95-96).

60. Friedländer (1997, p. 17).

61. Koonz (2003, p. 38).

62. Schleunes (1970, p. 66). 
63. $\operatorname{Koonz}(2003$, p. 84).

64. Quoted in Koonz (2003, p. 85).

65. Browning $(2004$, p. 9$)$.

66. Schleunes (1970, p. 94).

67. Schleunes (1970, pp. 62-91).

68. Krausnick and Broszat (1970, p. 44).

69. Schleunes (1970, pp. 102-109).

70. See Goldhagen (1996, pp. 90-95) and Koonz (2003, pp. 37-38).

71. Höhne (1984, p. 145, as cited in Markusen and Kopf 1995, p. 124).

72. Browning $(1978$, p. 3$)$.

73. Quoted in Koonz (2003, p. 98).

74. Koonz (2003, pp. 49-56, 68).

75. As Hitler said in his 1934 essay The Führer Protects the Law, "If I am reproached with not turning to the law-courts for sentences, I can only say in this hour, I was responsible for the fate of the German nation and thereby the supreme judge of the German people" (quoted in Kershaw 1998 , p. 519, as cited in Reemtsma 2012, p. 183).

76. $\operatorname{Koonz}(2003$, p. 99).

77. Browning $(1978$, p. 3$)$.

78. Koonz (2003, p. 187).

79. $\operatorname{Koonz}(2003$, p. 171).

80. Hancock (1988, p. 59, as cited in Markusen and Kopf 1995, p. 124).

81. Browning (1978, p. 4).

82. Johnson and Reuband (2005, p. 340). Ironically, these successful and popular policies were the brainchild of the last Weimar Republic Chancellor Kurt von Schleicher and his "pro-labour measures" (Cesarani 2016, p. 29).

83. Aly (2006, p. 3). See also Aly (2006, pp. 317-318).

84. Quoted in Johnson and Reuband (2005, p. 177).

85. Cesarani (2016, p. 52). See also Aly (2006, p. 21).

86. $\operatorname{Koonz}(2003$, p. 81$)$.

87. Cesarani (2016, pp. 135, 162, 210) and Koonz (2003, pp. 191-192).

88. Koonz (2003, pp. 191-192).

89. Aly (2006, p. 21$)$.

90. Schäfer $(2009$, p. 18 , as cited in Neitzel and Welzer 2012, p. 33).

91. Schäfer $(2009$, p. 12, as cited in Neitzel and Welzer 2012, p. 33).

92. Cesarani (2016, p. 12).

93. Schäfer $(2009$, p. 18 , as cited in Neitzel and Welzer 2012, p. 33).

94. Aly (2006, pp. 4, 41, 48).

95. Browning (1978, p. 2).

96. Breton and Wintrobe (1986, pp. 911-916).

97. Quoted in Bloxham and Kushner (2005, p. 127).

98. Browning (1978, p. 82). 
99. Browning (2004, p. 37$)$.

100. Quoted in Matthäus (2007, p. 234).

101. Aly (2006, p. 24).

102. Quoted in Browning (2004, p. 243).

103. See Longerich (2005, p. 214).

104. Schleunes (1970, p. 216).

105. Wilhelm (1997, p. 118).

106. Wilhelm (1997, pp. 118-119).

107. Browning (1978, p. 17).

108. Kershaw (2000, pp. 109-110).

109. The closest modern parallel was perhaps the 1905 pogrom in Odessa, Ukrainian.

110. See Kershaw (1983, pp. 262-263) and Browning (2004, pp. 9-10).

111. Schleunes (1970, pp. 214-254).

112. Schleunes (1970, p. 229).

113. Markusen and $\operatorname{Kopf}(1995$, p. 125).

114. Browning (1978, p. 5).

115. Quoted in Cesarani (2004, p. 67).

116. Schleunes (1970, p. 216).

117. Rubenstein (1978, p. 27).

118. Browning (1978, p. 5$)$.

119. Browning (1978, pp. 6, 19).

120. Fleming (1984, p. 43).

121. This was because Hitler "instinctively" sympathized with the "strongarm" sector of the Nazi regime (see Mommsen 1986, pp. 102, 107).

122. Quoted in Friedländer (1997, pp. 309-310).

123. Koonz (2003, p. 100).

124. Cesarani (2016, p. 226).

125. Victor (1998, p. 55, as cited in Rhodes 2002 , p. 28 ).

126. See Middlebrook (2006).

127. Bartov (1996, p. 50).

128. Quoted in Glover (1999, p. 321$)$.

129. Toland (1976, p. 702). See Madley (2015) for more on the American genocide debate.

130. See Colins (2004, as cited in De Swaan 2015, p. 43).

131. See Fleming (1984, pp. 30, 44).

132. Kershaw (1983, pp. 262-263) argues that among most people there was a "broad swell of disapproval" and "disgust" with Kristallnacht-a point supported by other specialist historians (see Browning 2004, pp. 9-10). But this disapproval was probably more about the actions than the target because not only were "'Dynamic' Jew-haters" a small minority of the population, active supporters of the Jews were even rarer (Kershaw 1983 , p. 275). 
133. Friedlander (1995, p. 126) and Koonz (2003, pp. 191-197).

134. Müller-Hill (1988, pp. 14, 18-19, 29).

135. Koonz (2003, pp. 195, 200).

136. Koonz (2003, pp. 201-202).

137. Koonz (2003, p. 191).

138. See Koonz (2003, pp. 195, 197, 199), Mosse (1966, pp. 59, 62, 65), and Müller-Hill (1988, pp. 12, 18, 19, 36, 37, 38, 41, 57, 61, 74, 79, $85-86,99)$.

139. Koonz (2003, p. 214).

140. Koonz (2003, p. 195).

141. Koonz (2003, pp. 196-197, 215).

142. Koonz (2003, pp. 197, 201-202).

143. Glover $(1999$, p. 384).

144. Glass (1997, p. 65), Glover (1999, pp. 366, 384), Sereny (1974, p. 62), and Westermann $(2005$, p. 36). The Nazis even imprisoned their most ardent supporters when they strayed from the party line (see Earl 2009, p. 149).

145. Glover (1999, p. 366).

146. This carefully crafted social environment shares some similarities with the Obedience studies. That is, Milgram also constructed an artificial social environment where, unlike outside the laboratory, participants were blocked from any sources of support for the widely accepted normative view that it is wrong to hurt an innocent person. On a microcosmic scale, Milgram also ensured that the abnormal became normal, and then this new normal appeared to be normative.

147. Bracher (1970, p. 269, as cited in Markusen and Kopf 1995, p. 212).

148. Mommsen (1986, p. 113).

149. See Bloxham and Kushner (2005, p. 122).

150. Kühl (2016, pp. 23, 195).

151. Stone (2010, pp. 101-102).

152. Koonz (2003, p. 135).

153. Cesarani (2016, p. 55).

154. Koonz (2003, p. 149).

155. Cesarani (2016, p. 51).

156. Cesarani (2016, p. 55).

157. Koonz (2003, pp. 156-162).

158. Cesarani (2016, pp. 51-52) and Markusen and Kopf (1995, p. 124).

159. Johnson and Reuband (2005, p. 347).

160. Quoted in Kühne $(2010$, p. 39). With intentions of ensuring the same outcome, officials from other government departments, for example, the Farmer's League, were known to take photos of non-Jewish Germans attending Jewish funerals (see Cesarani 2016, p. 119). Similarly, if the wives of Nazi leaders or civil service workers continued to shop at Jewish-owned stores, they could find their names published in Der Stürmer (Koonz 2003, p. 44). 
161. Friedländer $(2007$, p. 53$)$.

162. Koonz (2003, p. 75$)$.

163. Kühl (2016, pp. 48-49).

164. See, for example, the carefully staged photograph of almost fifty young wide-eyed Germans clambering over themselves to hear the Führer's (apparently) magical words of wisdom (Koonz 2003, p. 82).

165. It can be argued that Milgram's baseline experiment utilized, as a binding mechanism, a type of fictional consensus-participants quickly discovered that unlike in the normal world, in Milgram's (purposefully) isolated laboratory setting, they were the only one with the power of choice that was against the infliction of excruciating shocks. Everybody else-the experimenter, his absent boss Dr. Milgram, and the all-powerful institution of Yale University-appeared to support the infliction of more shocks. With no social support in favor of their preference, most socially isolated participants retreated into a critical silence and caved to the environment's new normal by doing as they were told.

166. Kühl (2016, p. 48). See also Kühne (2010, p. 156) and Longerich (2010, pp. 31-32).

167. Storjohann (1993, p. 100, as cited in Kühl 2016, p. 49).

168. Mosse (1966, p. 59) argues, "Instruction in race became compulsory in the Prussian schools after September 1933 and eventually in all German schools. Secondary schools were required to teach heredity, racial science, and family as well as population policies."

169. Mommsen (1986, p. 101) and Koonz (2003, p. 117).

170. Cesarani $(2016$, p. 54).

171. Koonz (2003, p. 192).

172. Koonz (2003, p. 125).

173. Friedländer $(2007$, p. 102$)$.

174. Cesarani (2016, p. 420).

175. Friedländer (2007, p. 100).

176. Quoted in Friedländer (2007, p. 100).

177. Quoted in Friedländer (2007, p. 100).

178. As Koonz (2003, p. 218) notes: "By the late 1930s it appeared that most Germans tacitly approved of persecution as long as they did not feel personally threatened or inconvenienced."

179. Quoted in Rees (2005, pp. 132-133).

180. Rees (2005, pp. 133-134).

181. Quoted in Klee et al. (1988, pp. 220-221). See also Kühne (2010, p. 72$)$.

182. Kühl (2016, p. 152). The inherent self-righteousness that many Germans felt in regard to their killing of "bad" people apparently "deserving of harm" is a volatile mind-set that I would argue is still 
quite common today. Consider, for example, that most viewers of Quentin Tarantino's blockbuster Inglorious Basterds are unlikely to question the immorality of the enormous amount of killing taking place before their eyes-Nazis are bad and therefore they deserve to be killed by the vengeful American Jewish soldiers. The irony is that just before and during World War Two, Nazis like Möbius could have watched a version of Inglorious Bastards-except with Nazis on a hunt in the forests for (apparent) partisan Jews - and he likely would have cheered along much as many viewers do today when the Nazis in Tarantino's original version get their comeuppance. Of course, there is great danger in this "good versus evil" narrative: People who kill for morally "good" reasons only end up providing the survivors of their attacks with the same morally self-righteous justification for then trying to kill them; thereby, potentially generating a never ending cycle of violence (Baumeister 1997, pp. 31-96).

183. In a confidential Easter message in 1933 to all his pastors, Bishop Otto Dibelius, a prominent German Protestant clergyman warned, "One cannot ignore that Jewry has played a leading role in all the destructive manifestations of modern civilization" (quoted in Friedländer 1997, p. 42). See also Wistrich (2001, p. 95).

184. Kühne (2010, pp. 60-62) and Neitzel and Welzer (2012, pp. 30-35, 149).

185. De Swaan $(2015$, p. 248).

186. Hayes $(2017$, p. 144).

187. This is according to Walter Gross, the Nazi physician and eventual head of the National Socialist Office of Racial Politics (quoted in Koonz 2003, p. 125).

188. Neitzel and Welzer (2012, p. 25$)$.

189. Baumeister (1997, pp. 31-96).

190. Neitzel and Welzer (2012, p. 9).

191. Koonz (2003, p. 29) and Baumeister (1997, pp. 34-38).

192. Neitzel and Welzer (2012, p. 13).

193. Fein (1979, p. 33$)$.

194. Kühl (2016, p. 55). Kühl adds: the main purpose of the "flood of propaganda - and the research literature often overlooks this - was not actually to directly motivate the men. Organizations can motivate their members much more easily by issuing specific instructions through their formal communication channels and by drawing up general regulations. Instead, my theory is that this ideological training ensured that the policemen's participation in ghetto clearances, deportations, and mass executions would fall within their zone of indifference" (2016, p. 54).

195. Kühl (2016, pp. 136-137). 
196. Quoted in Rossino (2003, p. 12).

197. Quoted in Rossino (2003, p. 15).

198. Quoted in Rossino (2003, p. 15).

199. Quoted in Breitman (1991, p. 43).

200. Quoted in Gilbert (1947, pp. 278-279).

201. Cesarani (2016, p. 231).

202. Koonz (2003, p. 222).

203. Koonz (2003, p. 7). On this note, consider, for example, L. Frank Baum, author of The Wizard of Oz, who said as a journalist in South Dakota in the late nineteenth century: "The Whites, by law of conquest, by justice of civilization, are masters of the American continent and the best safety of the frontier settlements will be secured by the total annihilation of the few remaining Indians. Why not annihilation? Their glory has fled, their spirit broken, their manhood effaced; better that they should die than live like miserable wretches that they are" (Stannard 1992, p. 126, as cited in Koonz 2003, p. 7).

204. Mommsen (1986, p. 115).

205. de Mildt (1996, p. 311$)$.

\section{REFERENCES}

Aly, G. (2006). Hitler's beneficiaries: Plunder, racial war, and the Nazi welfare state. New York: Metropolitan Books, Henry Holt and Company.

Arendt, H. (1958). The origins of totalitarianism. New York: The World Publishing Company.

Bartov, O. (1996). Murder in our midst: The Holocaust, industrial killing, and representation. New York: Oxford University Press.

Bauer, Y. (2001). Rethinking the Holocaust. New Haven, CT: Yale University Press.

Baumeister, R. F. (1997). Evil: Inside human cruelty and violence. New York: W. H. Freeman.

Baur, E., Fischer, E., \& Lenz, F. (1921). Grundriss der menschlichen Erblichkeitslehre und Rassenhygiene (2 Bde). München: J.F. Lehmann Verlag.

Bloxham, D., \& Kushner, T. (2005). The Holocaust: Critical historical approaches. Manchester, UK: Manchester University Press.

Breitman, R. (1991). The architect of genocide: Himmler and the final solution. New York: Alfred A. Knopf.

Breitman, R. (2000). Official secrets: What the Nazis planned, what the British and Americans knew. London: Penguin Books.

Breton, A., \& Wintrobe, R. (1986). The bureaucracy of murder revisited. The Journal of Political Economy, 94(5), 905-926. 
Browning, C. R. (1978). The final solution and the German Foreign Office: A study of Referat D III of Abteilung Deutschland 1940-1943. New York: Holmes and Meier.

Browning, C. R. (2004). The origins of the final solution: The evolution of Nazi Jewish policy, September 1939-March 1942. Lincoln: University of Nebraska Press.

Burleigh, M., \& Wippermann, W. (1991). The racial state: Germany 1933-1945. New York: Cambridge University Press.

Cesarani, D. (2004). Eichmann: His life and crimes. London: William Heinemann.

Cesarani, D. (2016). Final solution: The fate of the Jews 1933-1949. London: Macmillan.

de Mildt, D. (1996). In the name of the people: Perpetrators of genocide in the reflection of their post-war prosecution in West Germany-The 'Euthanasia' and 'Aktion Reinhard' trial cases. London: Martinus Nijhoff.

De Swaan, A. (2015). The killing compartments: The mentality of mass murder. New Haven, CT: Yale University Press.

Earl, H. C. (2009). The Nuremberg SS-Einsatzgruppen trial, 1945-1958: Atrocity, law, and history. Cambridge, UK: Cambridge University Press.

Fein, H. (1979). Accounting for genocide: National responses and Jewish victimization during the Holocaust. Chicago: University of Chicago Press.

Fest, J. C. (1974). Hitler: Translated from the German by Richard and Clara Winston. New York: Harcourt Brace Jovanovich.

Fleming, G. (1984). Hitler and the final solution. Berkeley: University of California Press.

Friedlander, H. (1995). The origins of Nazi genocide: From euthanasia to the final solution. Chapel Hill: University of North Carolina Press.

Friedländer, S. (1997). Nazi Germany and the Jews: The years of persecution, 1933-1939. New York: HarperCollins.

Friedländer, S. (2007). The years of extermination: Nazi Germany and the Jews, 1939-1945. New York: Harper Perennial.

Gilbert, G. M. (1947). Nuremberg diary. New York: Farrar, Straus, and Company.

Glass, J. M. (1997). Life unworthy of life: Racial phobia and mass murder in Hitler's Germany. New York: Basic Books.

Glover, J. (1999). Humanity: A moral history of the twentieth century. London: Pimlico.

Goldhagen, D. J. (1996). Hitler's willing executioners: Ordinary Germans and the Holocaust. London: Alfred A. Knopf.

Hayes, P. (2017). Why? Explaining the Holocaust. New York: W. W. Norton.

Hett, B. C. (2014). Burning the Reichstag: An investigation into the Third Reich's enduring mystery. New York: Oxford University Press. 
Hitler, A. (1943). Mein Kampf. Boston: Houghton Mifflin.

Hitler, A. (2013). Hitler's table talk 1941-1944: Secret conversations (H. R. Trevor-Roper \& G. L. Weinberg, Ed.). New York: Enigma Books.

Johnson, E. A., \& Reuband, K. H. (2005). What we knew: Terror, mass murder and everyday life in Nazi Germany, an oral history. London: John Murray.

Kershaw, I. (1983). Popular opinion and political dissent in the Third Reich: Bavaria 1933-1945. Oxford, UK: Oxford University Press.

Kershaw, I. (2000). The Nazi dictatorship: Problems and perspectives of interpretation (2nd ed.). London: Arnold.

Klautke, E. (2016). 'The Germans are beating us at our own game': American eugenics and the German sterilization law of 1933. History of the Human Sciences, 29(3), 25-43.

Klee, E., Dressen, W., \& Riess, V. (Eds.). (1988). "The good old days": The Holocaust as seen by its perpetrators and bystanders. New York: Free Press.

Koonz, C. (2003). The Nazi conscience. London: The Belknap Press of Harvard University Press.

Krausnick, H., \& Broszat, M. (1970). Anatomy of the SS State. St Albans, UK: Paladin.

Kühl, S. (2016). Ordinary organizations: Why normal men carried out the Holocaust. Cambridge, UK: Polity Press.

Kühne, T. (2010). Belonging and genocide. New Haven: Yale University Press.

Landau, R. S. (1994). The Nazi Holocaust: Its meaning for all the world's peoples-And its moral, ethical, and psychological implications. Chicago: Ivan R. Dee.

Lifton, R. J. (1986). The Nazi doctors: Medical killing and the psychology of genocide. New York: Basic Books.

Longerich, P. (2005). From mass murder to the "final solution": The shooting of Jewish civilians during the first months of the Eastern campaign within the context of the Nazi Jewish genocide. In S. Gigliotti \& B. Lang (Eds.), The Holocaust: A reader (pp. 198-219). Oxford, UK: Blackwell.

Longerich, P. (2010). Holocaust: The Nazi persecution and murder of the Jews. Oxford, UK: Oxford University Press.

Madley, B. (2015). Reexamining the American genocide debate: Meaning, historiography, and new methods. The American Historical Review, 120(1), 98-139.

Markusen, E., \& Kopf, D. (1995). The Holocaust and strategic bombing: Genocide and total war in the twentieth century. Boulder, CO: Westview Press.

Matthäus, J. (2007). Controlled escalation: Himmler's men in the summer of 1941 and the Holocaust in the occupied Soviet territories. Holocaust and Genocide Studies, 21(2), 218-242.

Middlebrook, M. (2006). The first day on the Somme. Barnsley, UK: Pen and Sword. 
Milgram, S. (1974). Obedience to authority: An experimental view. New York: Harper and Row.

Mommsen, H. (1986). The realization of the unthinkable: The 'final solution of the Jewish question' in the Third Reich. In G. Hirschfeld (Ed.), The policies of genocide: Jews and Soviet prisoners of war in Nazi Germany (pp. 97-144). London: Allan \& Unwin.

Mosse, G. (1966). Nazi culture: Intellectual, cultural, and social life in the Third Reich. New York: Grosset and Dunlap.

Müller-Hill, B. (1988). Murderous science: Elimination by scientific selection of Jews, Gypsies, and others, Germany 1933-1945. New York: Oxford University Press.

Neitzel, S., \& Welzer, H. (2012). Soldiers: On fighting, killing and dying: The secret Second World War transcripts of German POWs. New York: Alfred A. Knopf.

Reemtsma, J. P. (2012). Trust and violence: An essay on a modern relationship. Princeton, NJ: Princeton University Press.

Rees, L. (2005). Auschwitz: A new history. New York: BBC Books.

Rhodes, R. (2002). Masters of death: The SS-Einsatzgruppen and the invention of the Holocaust. New York: Alfred A. Knopf.

Rossino, A. (2003). Hitler strikes Poland: Blitzkrieg, ideology, and atrocity. Lawrence: University Press of Kansas.

Rubenstein, R. (1978). The cunning of history: The Holocaust and the American future. New York: HarperCollins.

Rubenstein, R. L., \& Roth, J. K. (1987). Approaches to Auschwitz: The Holocaust and its legacy. Atlanta, GA: John Knox Press.

Rutherford, P. T. (2007). Prelude to the final solution. Lawrence: University of Kansas.

Schleunes, K. A. (1970). The twisted road to Auschwitz: Nazi policy toward German Jews, 1933-1939. Chicago: University of Illinois Press.

Sereny, G. (1974). Into that darkness: From mercy killing to mass murder. London: Pimlico.

Stone, D. (2010). Histories of the Holocaust. Oxford, UK: Oxford University Press.

Toland, J. (1976). Adolf Hitler. New York: Doubleday.

Traverso, E. (2003). The origins of Nazi violence. New York: The New Press.

van Pelt, R. J., \& Dwork, D. (1996). Auschwitz: 1270 to the present. New York: W. W. Norton.

Waite, R. G. L. (2000). The Holocaust and historical explanation. In I. Willimann \& M. N. Dobkowski (Eds.), Genocide and the modern age: Etiology and case studies of mass death (pp. 163-184). Syracuse, NY: Syracuse University Press. 
Westermann, E. B. (2005). Hitler's police battalions: Enforcing racial war in the east. Lawrence: University Press of Kansas.

Wilhelm, H. (1997). "Inventing" the Holocaust for Latvia. In Z. Gitelman (Ed.), Bitter legacy: Confronting the Holocaust in the USSR (pp. 104-122). Bloomington: Indiana University Press.

Wistrich, R. S. (2001). Hitler and the Holocaust: How and why the Holocaust happened. Toronto, ON: Random House of Canada Limited.

Open Access This chapter is licensed under the terms of the Creative Commons Attribution 4.0 International License (http://creativecommons.org/licenses/ by $/ 4.0 /)$, which permits use, sharing, adaptation, distribution and reproduction in any medium or format, as long as you give appropriate credit to the original author(s) and the source, provide a link to the Creative Commons licence and indicate if changes were made.

The images or other third party material in this chapter are included in the chapter's Creative Commons licence, unless indicated otherwise in a credit line to the material. If material is not included in the chapter's Creative Commons licence and your intended use is not permitted by statutory regulation or exceeds the permitted use, you will need to obtain permission directly from the copyright holder.

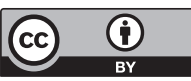

